\title{
Erratum to: Latitudinal dependence of body condition, growth rate, and stable isotopes of juvenile capelin (Mallotus villosus) in the Bering and Chukchi Seas
}

Mark B. Barton ${ }^{1} \cdot$ John R. Moran ${ }^{2} \cdot$ Johanna J. Vollenweider $^{2} \cdot$ Ron A. Heintz ${ }^{2}$. Kevin M. Boswell ${ }^{1}$

Published online: 11 April 2017

(C) Springer-Verlag Berlin Heidelberg 2017

\section{Erratum to: Polar Biol}

DOI 10.1007/s00300-016-2041-8

The author's have supplied an updated Fig. 3, please see below.

The original article was corrected.

The online version of the original article can be found under doi: 10.1007/s00300-016-2041-8.

Mark B. Barton

Mbart034@fiu.edu

1 Department of Biological Sciences, Marine Sciences

Program, Florida International University, 3000 NE 151st St,

North Miami, FL 33181, USA

2 Auke Bay Laboratories, Alaska Fisheries Science Center,

National Marine Fisheries Service, NOAA, 17109 Pt. Lena

Loop Rd., Juneau, AK 99801, USA 

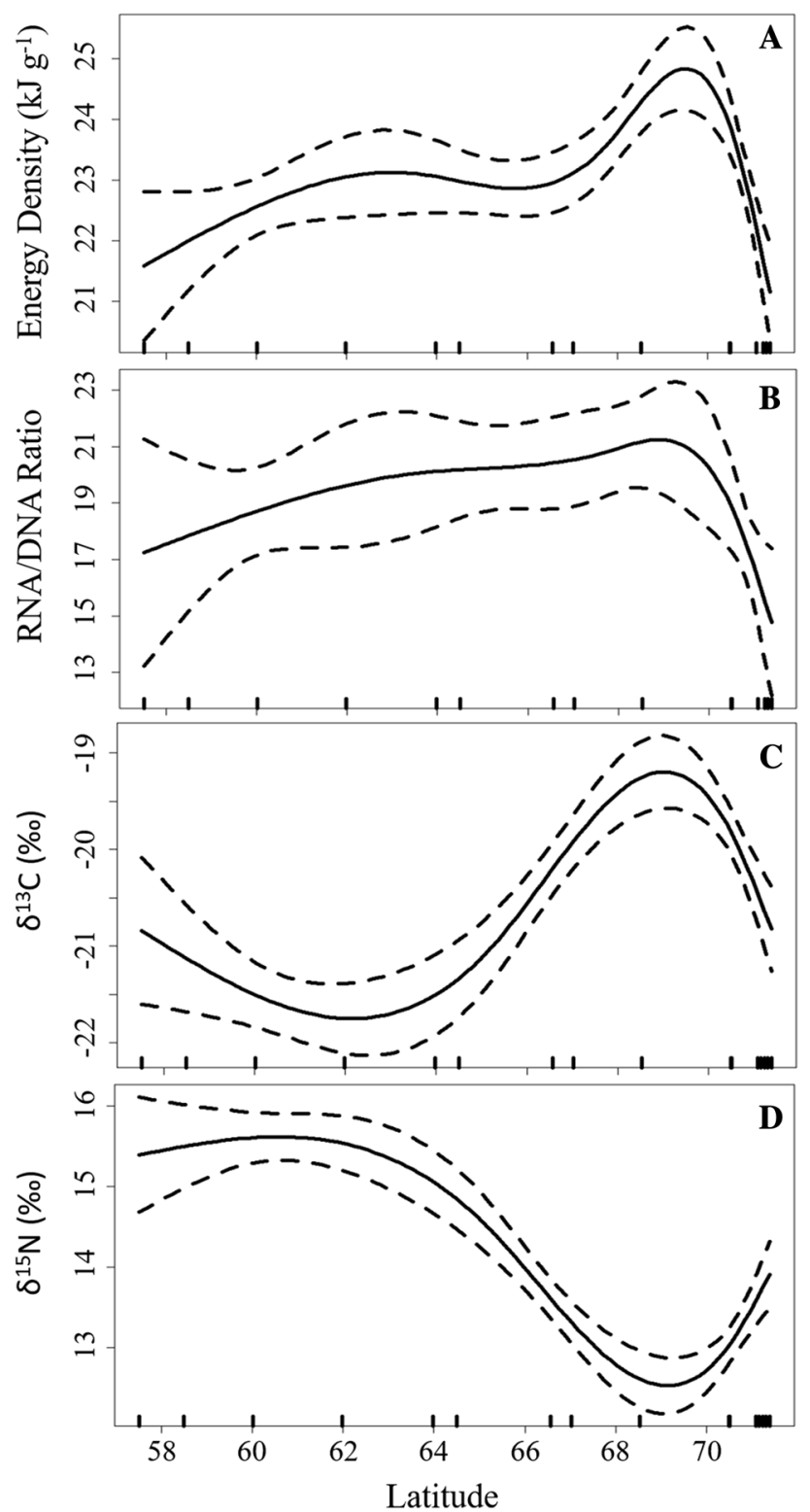

Fig. 3 General additive models for energy density (a), RNA/ DNA ratios (b), $\delta^{13} \mathrm{C}(\mathbf{c})$, and $\delta^{15} \mathrm{~N}$ (d) for all juvenile capelin with a smoothing function on latitude. All models created using cubic splines were used with five knots $($ edf $=4)$ for energy density and RNA/DNA ratios, and four knots (edf $=3$ ) for $\delta^{13} \mathrm{C}$ and $\delta^{15} \mathrm{~N}$. The dashed lines represent the $95 \%$ confidence interval. Each model was significant with varying levels of deviance explained (A: $R^{2}=0.34$, $p<0.0001$; $\mathrm{B}: R^{2}=0.14, p=0.01 ; \mathrm{C}: R^{2}=0.54, p<0.0001$; $\left.R^{2}=0.67, p<0.0001\right)$. The bold tick marks above the $\mathrm{x}$-axis represent latitudes at which fish samples were collected 